among university delegates to a conference called jointly by the Committee of Vice-Chancellors and the Associalion of University Teachers on March 21, the cause of university productivity has made some worthwhile advances since the Committee of ViceChancellors first took an official interest in the subject two years ago. It is hard, however, to tell precisely how the universitics reacted to some of the proposals now being made, for the universities seem to be as jealous of the privacy of their discussions as of any other academic freedom.

The conference on March 21 was opened by Mr C. F. Carter, vice-chancellor of the University of Lancaster and the British prophet of university productivity. The essence of his ease was that teachers, and the way in which their work is organized, are more immediate limitations of the output of qualified students from universities than are buildings and other kinds of equipment, so that "increases of productivity are thercfore most likely to be achieved by a better organization of labour or by harder work". Both in teaching and in research, according to Mr Carter, better productivity could be obtained by having fewer small departments, by not using highly trained staff for work that could be done by others, by spending more capital on educational technology, by organizing staff time more efficiently and by working harder. "And why not? American academics do. It would help if more payment was on piece rates." Mr Carter would also like to see a redefinition of the division between teaching and research, and he considers that the more efficiont use of buildings would make it possible for universities to double student numbers "even before using such obvious expedients as lengthening the very short teaching day". In Mr Carter's view, the university year should be organized on a staggered pattern with each student sponding two out of three equal terms at the university each year. He wants to sec more sharing of expensive equipment, a reduction of committee work and "a drastic reduction in the circulation of paper".

How did all this go down? Several speakers at the conference were more concerned than Mr Carter with the philosophical definition of what is meant by university productivity. Something of this sort may cventually come from the work of $\mathrm{Mr} \mathrm{K}$. S. Davies, seconded to the Committee of Vice-Chancellors as a research officer, who is engaged on a long-term study of the factors which affect university productivity. Dr M. Blaug, of the University of London Institute of Education, took a still longer look at the problem of measurcment, and was particularly anxious that the concepts of productivity and efficiency should not be confused. He would like there to be a continuing comparison of scores in student attainment tests at the beginning and at the end of university courses, studies by educational psychologists of the effectiveness of different teaching methods, more information about the socio-economic character of students and about their economic prospects, and some attempt to construct objective vardsticks for the evaluation of research.

It seems that only a minority of those present thought that studies of this sort were undesirable. One count showed that only three out of lwenty-four speakers werc against, with the rest in favour. 'This marks a great change of opinion in the past five years. It even seems to have been possible for Mr Carter to get away with the claim that university teachers in the United States work harder than those in Britain. Dr D. G. Christopherson, chairman of the Committec of Vice-Chancellors, said after the meeting that the universities did not feel themselves to be under immediate pressure. Thcy were, he said, looking forward to the next period of fast expansion in the seventies. And the suggestion that the universities fear that if they do not begin to measure their own productivity, somebody less sympathetie will come along and do it for them was indignantly denied. Professor Blaug called it "an uncharitable suggestion".

\section{Rockefeller Without Bronk}

\section{New York, March}

THE resignation of Dr Detlev W. Bronk as president of the Rockefeller University later this year will amount to something like the end of an era in the affairs of the university, until 1964 the Rockefeller Institute. By common consent, Dr Bronk has been almost entirely responsible for the directions which the institute's growth has followed since his accession to the presidency in 1953 (after several years as president at Johns Hopkins). He has been consistently expansionist, with the result that the faculty has grown in size and lustre. He has also consistently fought for a recognition of the educational responsibilities of the people at the Rockefeller Institute, which is how the institute has acquired the distinction of being an inde-

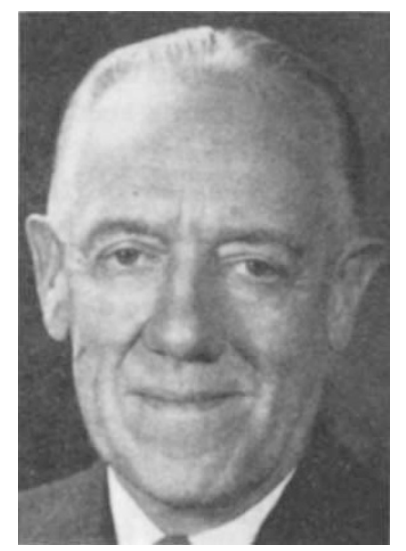
pendent university without undergraduates. Although there are few among the faculty who are unmoved by Dr Bronk's vision of the part his institution might play in the academic life of the United States, there have frequently been occasions when the president and the faculty have moved ahead at different spoeds. The creation, within the past year, of an academic council at the Rockefeller University should help to ensure that the balance of power between the faculty and Dr Bronk's successor is more even.

'There is no doubt that Dr Bronk's carcer is one of almost unparalleled distinction. For several years he has divided his immense energy between government and universities. His spell as president of the United States National Academy of Sciences, between 1950 and 1962, saw a vigorous growth of the academy's influcnce in Washington and elsewhere, largely as a result of the drive which Dr Bronk imparted to the job. In the circumstances, it is not surprising that Dr Bronk should plan not to settle back into retirement when his present appointment ends. He says that he will keep on a laboratory at the Rockefeller University, as is the custom for retired professors at the institution. At least until the election campaign is further advanced, he says that he intends to maintain a "flexible" position, which presumably implies that he will be ready to accept a call to another Washington job. In any 
case, Dr Bronk is personally deeply engaged in trying to bring science and technology to bear on the formidable problems of the city of New York. He says that a deeper involvement in social problems is one of his wishes for the future of the Rockefeller University. He would also like to see the institution become even more successful than at present at interdisciplinary studies.

Of Dr Bronk's successor at the university, there is as yet no news. Several distinguished names have been whispered in this connexion. There seems to be something in the view that Dr Frederick Seitz, now president of the National Academy, has been approached. It would, of course, be something of a feather in the university's cap if there were two examples to support the generalization that presidents of the academy habitually succeed to the presidency of the university.

\section{De-specialization}

A JoINT working party is to be set up by the Schools Council and the Standing Conference on University Entrance (SCUE) to examine proposals for broadening the British sixth form curriculum. The position of sixth formers not wishing to go on to university is to be investigated by a second working party which is to be set up by the Schools Council alone. The two parties will work side by side, with a possibility of overlapping membership. While welcoming the move towards broader curricula in schools, the universities see the Schools Council proposals for two A-levels and accompanying "elective courses" (Working Paper 16) as an encouragement to further specialization (see Nature, 216,1260 ; 1967). A meeting of SCUE last week collected together the comments of the universities and the announcement of the working parties soon followed.

As well as reducing specialization, reform of sixth form curricula will, it is hoped, delay the point at which pupils decide what subjects they will study at university. The universities see experimental curricula as an essential step towards reform, and are prepared to adapt their entrance requirements so as not to prejudice the chances of those pupils who act as guinea pigs. Current curriculum revision by the examining boards and the Nuffield Science Teaching Project is welcomed by the universities, but they would like to see further intensive studies of syllabus-making and examination techniques, with emphasis on the balance between facts, imagination, analysis and presentation. The universities express a doubt that "there yet exists any adequate alternative to externally examined courses as the main basis for sixth form preparation, and selection, of entrants", but at the same time suggest that the "introduction of an element of internal assessment into the examining system merits consideration". A scheme for four or five equivalent two-year courses spanning arts and science subjects is suggested as worthy of experiment, despite teaching difficulties and the resulting lowering of final examination standards. Following on from this the question arises whether an appropriate first degree standard can be reached in three years.

On the basis of this combined view, the universitics are joining with the Schools Council to discuss all the proposals so far put forward. The second working party will be concerned with sixth formers not intending to go to university, with regard for qualifications required by industry and commerce. A successful curriculum will obviously have to cater for those both above and below the academic salt, so that pupils are free to decide on their future during their last year at school.

Other aspects of the move away from specialization were discussed at a meeting at Queen Elizabeth College last week of some 140 sixth form science teachers and a sprinkling of university staff. Dr J. E. Spice from Winchester described the workings of the Nuffield physical sciences A-level course which is now on trial in 58 schools throughout the country. In combining chemistry and physics as one A-level subject, the physical science course allows biologists, for example, to take mathematics within the three A-level pattern. The overall comment on the joint course was favourable, from both schools and universities, despite strong words from some quartersnotably from Dr E. R. Roberts of Imperial College, a chemist who regretted the dearth of chemical facts in the course. From the physics side at Imperial College, Dr H. J. Pain retaliated in favour of students who have taken this course, preferring their ability to think to a stream of well-learned facts. There were murmurs from chemistry staff who are beginning to teach the physics side of the course to the effect that they themselves can at last understand the physics they learnt at school.

The new London BSe system, now in its second year, allows students to delay their final choice of subject until the end of the first year. Professor R. E. Burge of Queen Elizabeth College described last week the workings of the system of equivalent course units and the possibilities of inter-college co-operation. By giving each college more control over its courses, the new system is more flexible and adaptable to new knowledge. With a minimum of eight of the equivalent units to be passed for a degree and a maximum of twelve, the new course provides for the wide range of ability now found in universities.

\section{Where To Put It}

As everyone had expected, choosing the site for the CERN $300 \mathrm{GeV}$ synchrotron is proving to be an extremely touchy business. Nine countries have offered sites but no decision was reached at the last meeting of the council of CERN which discussed the recently published final report of the Site Evaluation Panel. The panel, consisting of three neutral representatives from countries which had not offered sites, has been working on the report since its appointment in 1966, and a separate geological survey of the sites has been prepared by Dr L. Bjerrum of Norway.

Based on the answers to the three questions of whether this laboratory can be built at the site (A), whether it can be operated there (B) and whether people will go there $(\mathrm{C})$, the panel concludes that Doberdô in Italy is the most suitable location. Le Lue in France is second best and the other sites all less suitable. (See table.)

With the future development of CERN likely to hang on the choice of site for the new accelerator, the panel is understandably cautious in its report. It 